\title{
Effect of different processing methods on nutritional composition of Leucaena leucocephala (Lam De Wit) leaves as inclusion in Fish Feed
}

\author{
${ }^{* 1}$ AGBO, AN; ${ }^{2}$ BALOGUN, JK; ${ }^{2}$ ONIYE, SJ; ${ }^{2}$ AUTA, J \\ ${ }^{1}$ Federal Department of Fisheries, Kaduna \\ ${ }^{2}$ Department of Biological Sciences, Ahmadu Bello University, Zaria \\ *ronkeagbo@yahoo.com
}

\begin{abstract}
The potentials of Leucaena leucocephala leaf-meal as a supplementary protein in fish feed was evaluated. Leucaena leaves were subjected to two processing methods (sundrying and boiling) to determine the effect of these treatments on proximate composition and anti-nutritional factors. Five samples of Leucaena leaves were analyzed, sundried for 24 hours $\left(\mathrm{SD}_{1}\right)$, sundried for 48 hours $\left(\mathrm{SD}_{2}\right)$, sundried for 72 hours $\left(\mathrm{SD}_{3}\right)$, soaked in boiled water for five minutes at $100^{\circ} \mathrm{C}\left(\mathrm{SB}_{5}\right)$ and unprocessed $(\mathrm{SU})$. The tests were carried out in triplicate for each treatment. Data obtained were subjected to one way analysis of variance. Sun-drying $\left(\mathrm{SD}_{1}, \mathrm{SD}_{2}\right.$, $\left.\mathrm{SD}_{3}\right)$ led to a significant $(\mathrm{P} \leq 0.05)$ increase in crude protein, ash, phosphorus, potassium, magnesium and sodium when compared with the soaked in boiled water $\left(100^{\circ} \mathrm{C}\right)$ for 5 minutes $\left(\mathrm{SB}_{5}\right)$ treatment. The sample soaked in boiled water for 5 minutes $\left(\mathrm{SB}_{5}\right)$ gave 73, 90, 81, 97 and $36 \%$ reduction in the levels of phytate, cyanide, tannin, saponin and mimosine respectively, which was better than the sundried treatments. ( ) JASEM

https://dx.doi.org/10.4314/jasem.v21i4.12
\end{abstract}

Key Words: Leucaena leucocephala, anti-nutritional factors, nutritional composition, supplementary protein, mimosine, fish feed.

The use of plant protein sources such as soyabeans and groundnut in fish diet may not be sustainable because they are good sources of protein for humans. There is therefore an urgent need to identify other protein rich plant resources that could substitute or supplement conventional protein feed ingredients. The nutritional interest in some of these vegetable species stems from their rich contents of essential amino acids, vitamins and minerals (Aye, 2012). However, the presence of inherent toxic factors or anti-nutritional components in plants has been one major obstacle in harnessing the full benefits of the nutritional value of plant proteins.

Leucaena leucocephala is a fast growing multipurpose legume that has been introduced to many tropical and subtropical countries (FACT, 1997). L. leucocephala belongs to the family Fabaceae, sub-family Mimosoidae. It has been documented that $L$. leucocephala was used in dry season feeding of ruminants, agro-forestation, wind breakers, live fence, alley farming, roadside landscaping, fuel production, paper production, timber production and nitrogen fixation (Hetrampf and Piedad-pascual, 2003). Leucaena leaf has crude protein values ranging from 15.2-34.3\% dry matter (FACT, 1997; Monoj and Bandyopadhay, 2007; Ayssiwede et al., 2011). The nutritional value of Leucaena in fish feed formulation has been limited due to the presence of a toxic nonprotein amino acid called mimosine (Hetrampf and Piedad-pascual, 2003). The level of mimosine can be reduced through processing (Monoj and Bandyopadhay, 2007). Thus simple and cost effective processing methods which the small-scale fishfarmers can adopt should be employed to reduce the levels of anti-nutritional factors.

The research evaluated the effects of processing on the proximate composition and anti-nutrients of $L$. leucocephala leaf-meal thereby assessing its potentials in supplementing conventional protein feed ingredients.

\section{MATERIALS AND METHODS}

Sample Collection: Leucaena leaves were collected from trees planted at the College of Agriculture and Animal Sciences, Mando, Kaduna and identified at the forage section of the National Animal Production Research Institute (NAPRI), Zaria. The leaves were handpicked and leaflets separated from the long leaf stalk.

Sample Treatment: The leaves were divided into five portions of $500 \mathrm{~g}$ each and subjected to two processing methods, namely sun-drying and boiling. The first $500 \mathrm{~g}$ of leaves were spread on a concrete slab outside the hatchery and sundried for 24 hours, another $500 \mathrm{~g}$ was sundried for 48 hours while the last $500 \mathrm{~g}$ was sundried for 72 hours (Ayssiwede et al., 2011). These were coded $\mathrm{SD}_{1}, \mathrm{SD}_{2}$ and $\mathrm{SD}_{3}$, respectively. Another leaf sample of $500 \mathrm{~g}$ was immersed in 1000 litres of 
boiled water $\left(100^{\circ} \mathrm{C}\right)$ for 5 minutes. The boiled Leucaena leaf sample was then sun-dried for 24 hours until it became crispy and coded $\mathrm{SB}_{5}$. The last sample (unprocessed) consists of $500 \mathrm{~g}$ Leucaena leaves and was coded SU which served as control. All the five leaf samples were ground into fine powder using a hammer mill, labeled and separately packed into polythene bags. These were stored for proximate, mineral and anti-nutrients analysis.

Proximate Analysis: Determination of ash content: Crucibles were cleaned and dried in the oven. After drying they were corked in the desiccator and weighed $\left(\mathrm{W}_{1}\right)$. After which $2 \mathrm{~g}$ of the grounded sample was placed in the crucible and weighed $\left(\mathrm{W}_{2}\right)$. These were transferred into furnace and set to $550^{\circ} \mathrm{C}$. The Sample was incinerated in the furnace for 8 hours. The crucible containing the ash was removed and cooled in the desiccator and weighed $\left(\mathrm{W}_{3}\right)$. The weight of the residue in the crucible corresponds to the organic matter content(AOAC, 1990).

Determination of moisture content (AOAC, 1990): Crucibles were washed and dried to a constant weight in an air oven at $100^{\circ} \mathrm{C}$, these were later removed and cooled in a desiccator and weighed $\left(\mathrm{W}_{1}\right)$. Two grams of the grounded sample was placed in the weighed moisture dish $\left(\mathrm{W}_{2}\right)$ the crucible containing the sample was kept in an oven at $100^{\circ} \mathrm{C}$ for 24 hours and weighed. It was kept back in the oven and reweighed after about 3 hours to ensure a constant weight $\left(\mathrm{W}_{3}\right)$. The moisture content was calculated as:

$\%$ Moisture $=\frac{\mathrm{W}_{2}-\mathrm{W}_{3} \quad \mathrm{X}}{\mathrm{W}_{2}-\mathrm{W}_{1}} \frac{100}{1}$

Determination of lipid content (AOAC, 1990):Two round bottom flasks were cleaned and few anti bump granules were added to prevent bumping. $300 \mathrm{mls}$ of petroleum ether $\left(40-60^{\circ} \mathrm{C}\right)$ boiling point were poured into the flask. These were fitted into the soxhlet extraction units. Extraction thimbles were weighed and approximately, $2.0 \mathrm{~g}$ of samples were weighed into it $\left(\mathrm{W}_{1}\right)$, the thimble was fixed into the soxhlet extraction unit with forceps and cold water circulation put on the heating mantle was switched on and solvent refluxing was adjusted at a steady rate. Extraction was carried out for eight hours. The thimble was removed and dried to constant weight in an oven at $70^{\circ} \mathrm{C}$ and was weighed $\left(\mathrm{W}_{2}\right)$. The extractible lipid was calculated as:

$\%$ Lipid $=$ Wt of lipid extracted $\mathrm{X} \quad 100$
Wt of dried sample

Where the weight of lipid extracted is given by the loss in weight

$\mathrm{W}_{1}-\mathrm{W}_{2}$ = weight of thimble content after extraction.

Determination of nitrogen and crude protein: The crude protein content of the samples was determined using the Microkjeldahl method of (AOAC, 1990) which involved protein digestion and distillation. a. Protein Digestion: About $2 \mathrm{~g}$ of the sample was weighed using Mettle 50 weighing balance into $100 \mathrm{ml}$ kjedahl flask and few antibump granules, one gram of catalyst $\left(\mathrm{K}_{2} \mathrm{SO}_{4}+\right.$ anh $\left.\mathrm{CuSO}_{4}\right)$ was added to speed up the reaction. The flask was fixed on the Kjeldahl digestion rack and heated slowly at first until fretting subsides and then more rigorously with occasional rotation of the flask to ensure even digestion and avoid over heating of content.b. Protein Distillation:After a clear solution was obtained, the sample was transferred to $100 \mathrm{ml}$ volumetric flask and diluted to mark with distilled water after cooling. $10 \mathrm{mls}$ of the diluted sample or digest was pipetted into Markham semi macro nitrogen still and $10 \mathrm{mls}$ of $40 \% \mathrm{NaOH}$ solution added. The sample was distilled liberating $\mathrm{NH}_{3}$ into $100 \mathrm{ml}$ conical flask containing $10 \mathrm{ml}$ of $40 \mathrm{ml}$ of $40 \%$ Boric acid and 2 drops of methyl red indicator. Distillation was continued until the pink colour of the indicator turned greenish. The control was titrated with $4 \%$ Boric acid with end point indicated by a change from greenish to pink colour. The volume of acid used for each sample distillate was noted as well as that of blank.

$\%$ total $\mathrm{N}$ per sample was calculated as:

$\% \mathrm{~N}=\mathrm{V}_{1}-\mathrm{V}_{0} \times \mathrm{M} \times 14 \times 100 \times 100$

$$
0.2 \times 1000 \times 10 \times 1
$$

$\mathrm{V}_{0}=$ vol. of $\mathrm{HCl}$ required for blank

$\mathrm{V}_{1}$-vol. of the $\mathrm{HCl}$ required for $10 \mathrm{ml}$ sample solution.

$\mathrm{M}=$ Molarity of acid $(0.1 \mathrm{~m})$

The crude protein was calculated as $\%$ crude protein $(\mathrm{cp})=6.25 \times \mathrm{N}$

NOTE: Protein contains $16 \% \mathrm{~N}_{2}$. This makes the general conversion factor to be 6.25

Determination of crude fibre (AOAC, 1990): Two grams of the grounded sample was placed in a round bottom flask. $100 \mathrm{ml}$ of $0.25 \mathrm{M} \mathrm{H}_{2} \mathrm{SO}_{4}$ was added and the mixture boiled under reflux for 30 minutes. The 
insoluble matter was washed several times with hot water until it was acid free. Thereafter, it was transferred into a flask containing $100 \mathrm{ml}$ of hot $0.312 \mathrm{M} \mathrm{NaOH}$ solution. The mixture was boiled again under reflux for 30 minutes and filtered under suction the insoluble residue was washed with hot water until it was base free. It was dried to constant weight in an oven at $100^{\circ} \mathrm{C}$, cooled in a desiccator and weighed $\left(\mathrm{C}_{2}\right)$. The weighed sample was incinerated in a furnace at $550^{\circ} \mathrm{C}$ for 2 hours. It was put off and allowed to cool down. It was removed cooled in a desiccator and weighed $\left(\mathrm{C}_{3}\right)$. The crude fibre was calculated as the loss in weight on ashing:

Weight of the original sample $=\mathrm{W}$

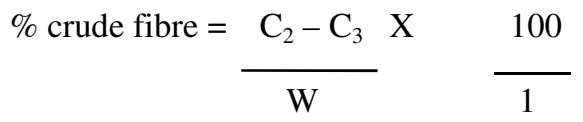

Nitrogen free extract: The nitrogen-free extract (NFE) which is the digestible portion of the carbohydrate contained in the sample and was determined by subtracting the percentage sums of moisture, crude protein, crude fat, crude fibre and ash from 100.

Energy values: The energy value of the leaf samples was calculated as described by Pauzenga (1985). Crude protein $\times 37$ + ether extract $\times 81.8$ + nitrogen free extract x 35 .

Determination of Anti-nutritional Compounds Cyanogenic glycoside: the procedure of AOAC (1990) was used in the determination of cyanogenic glycosides. Five grams of sample was placed in a $200 \mathrm{ml}$ conical flask, $50 \mathrm{ml}$ of distilled water was added. The content of the flask was stirred and allowed to stand for 4 hours. The filtrate was collected into a beaker using glass wool which was placed in a funnel. The filtrate was steam distilled into $20 \mathrm{ml}$ of $2.5 \%$ Sodium hydroxide. About $75 \mathrm{ml}$ of the distillate was collected. This was titrated with $0.02 \mathrm{~N}$ Silver nitrate after the addition of $8 \mathrm{ml}$ of $6 \mathrm{~N}$ Ammonium hydroxide and $2 \mathrm{ml}$ of $2 \%$ Potassium iodide. Permanent turbidity indicated end point.

\section{$1 \mathrm{ml} 0.02 \mathrm{~N} \mathrm{AgNO}_{3}=1.08 \mathrm{mg} \mathrm{HCN}$}

Phytic acid: Phytate phosphorus was determined by the method of Wheeler and Ferrel (1971). Approximately $2.0 \mathrm{~g}$ of the dried sample was soaked into $100 \mathrm{ml}$ of $2 \%$ $\mathrm{HC} 1$ for 5 hours and filtered $25 \mathrm{~cm}^{3}$ of the filtrate was taken into a conical flask. $5 \mathrm{~cm}^{3}$ of $0.3 \%$ potassium thiocynate solution was added. The mixture was titrated with standard solution of $\mathrm{FeCl}_{3}$. A standard curve was prepared expressing the results as $\mathrm{Fe}\left(\mathrm{NO}_{3}\right)_{3}$ equivalent.

Tannin: Tannin was determined using the standard method described by AOAC (1990). Two grams of the dried sample was boiled with $300 \mathrm{ml}$ of distilled water. This was diluted in a standard volumetric flask and filtered through a non-absorbent cotton wool. A volume of $25 \mathrm{ml}$ of the infusion was measured into a 2 litre porcelain dish and titrated with $0.1 \mathrm{~N}$ potassium permanganate $(0.1 \mathrm{~N}$ potassium permanganate was standardized against $0.1 \mathrm{~N}$ oxalic acid) until the blue solution changed green, then few drops of $0.1 \mathrm{~N}-9.005$ potassium permanganate was added. The titre was multiplied by 0.0066235 to obtain the amount of tannin in the sample as shown in the equation is below:

$0.1 \mathrm{~N}$ oxalic acid $=0.0066235 \mathrm{~g}$ tannin

Saponin: The standard method of AOAC (1990) was used to determined saponin in the samples. A gravimetric method employing the use of a soxhlet extractor and two different organic solvents was used. The first solvent extracts lipids and interfering pigments while the second solvent extracts the saponin proper. Five grams of the dried ground sample was weighed into a thimble and transferred into the soxhlet extraction chamber fitted with a condenser and round bottom flask. Some quantity of acetone enough to cause a reflux was poured into the flask. The sample was exhaustively extracted of its lipids and interfering pigments for 3 hours by heating the flask on a hotplate and the solvent was distilled off. For the second extraction, a pre-weighed round-bottom flask was fitted into the soxhlet apparatus which bore the thimble containing the sample. Then methanol was poured into the flask. The methanol was enough to cause reflux. The saponin was then exhaustively extracted for 3 hours by heating the flask on a hotplate after which the solvent was distilled off. The flask was reweighed. The difference between the final and initial weights of the flask represented the weight of the saponins extracted.

$$
\% \text { Saponins }=\frac{\text { Weight of saponins } X}{\text { Weight of sample }} 100
$$

Determination of mimosine: The mimosine content of the leaf meal was determined by the rapid colorimetric method of Megarity (1978). To extract the mimosine, about $2 \mathrm{~g}$ of sample was digested with $0.1 \mathrm{~N} \mathrm{HC1}$, filtered and clarified by removing plant pigments with activated carbon. Ferric chloride $(0.5 \%)$ was then added to the mimosine extracts to develop a coloured compound, the intensity of which was estimated by measuring the absorbance at $535 \mathrm{~nm}$ in a PyeUnicam 
PU 8650 visible spectrophotometer. The concentration of mimosine was then calculated from a standard curve using pure mimosine.

Determination of the Mineral Content: Mineral Content samples were determined by the methods of (AOAC, 1990). Digestion: One gram of each sample was weighted into a clean dried crucible and placed in a furnace. The temperature was raised to $550^{\circ} \mathrm{C}$ and allowed to ash for 3 hours. The contents were cooled, and $10 \mathrm{ml}$ of Aqua regia was added to the sample in crucible and then filtered into a $25 \mathrm{ml}$ volumetric flask to make up to volume with de-ionised water. Calcium, magnesium and sodium were read with PG 990 Atomic Absorption Spectrophotometer and potassium was read using Jenway flame photometer. Phosphorus was analysed when a sample of $1 \mathrm{ml}$ aliquot of the plant extract was pipette into a $25 \mathrm{ml}$ volumetric flask and $10 \mathrm{ml}$ distilled water was added, $4 \mathrm{ml}$ of Molybdate reagent was then added to make up to $25 \mathrm{ml}$ with distilled water and allowed to stand for 15 minutes for the colour to develop. The phosphorus content in solution was then determined on a Jenway 6705 uv/vis spectrophotometer.

Statistical analysis: One way analysis of variance (ANOVA) was used to analyze data collected. The means were separated using Duncan's multiple range test at $95 \%$ confidence limit.

\section{RESULT AND DISCUSSION}

The result from Table1 shows that the crude protein in the sun-dried treatments were higher than the sample soaked in boiled water $\left(100^{\circ} \mathrm{C}\right)$ for 5 minutes $\mathrm{SB}_{5}$. Treatment $\mathrm{SD}_{3}$ (sundried for 72 hours) had the highest crude protein of $33.22 \%$ followed by $\mathrm{SD}_{2}$ (sundried for 48 hours) with $31.83 \%$ and then $\mathrm{SD}_{1}$ (sundried for 24 hours) $30.66 \%$ while $\left(\mathrm{SB}_{5}\right)$ soaked in boiled water $\left(100^{\circ} \mathrm{C}\right)$ for 5 minutes had $28.33 \%$. The crude protein value in the sundried treatments $\left(\mathrm{SD}_{1}, \mathrm{SD}_{2}\right.$ and $\left.\mathrm{SD}_{3}\right)$ were significantly different $(\mathrm{P} \leq 0.05)$ from the $\left(\mathrm{SB}_{5}\right)$ treatment. The crude fibre content of the sundried treatments was significantly different $(\mathrm{P} \leq 0.05)$ from the soaked in boiled water $100^{\circ} \mathrm{C}$ for 5 minutes $\left(\mathrm{SB}_{5}\right)$ treatment.

Table 1: Effects of processing on the Proximate Composition of Leucaena leucocephala Leaves

\begin{tabular}{|c|c|c|c|c|c|}
\hline Treatment $(\mathrm{g} / \mathbf{1 0 0 g})$ & SU & $\overline{\text { SD }_{1}}$ & $\mathbf{S D}_{2}$ & $\mathrm{SD}_{3}$ & $\mathbf{S B}_{5}$ \\
\hline Ash & $4.6 \pm 1.98^{\mathrm{b}}$ & $7.00 \pm 1.00^{\mathrm{a}}$ & ${ }^{c} 7.00 \pm 0.00^{\mathrm{a}}$ & $7.00 \pm 0.00^{\mathrm{a}}$ & $6.33 \pm 0.58^{\mathrm{ab}}$ \\
\hline Ether extract & $6.03 \pm 1.97^{\mathrm{a}}$ & $5.00 \pm 0.00^{\mathrm{a}}$ & $5.67 \pm 0.58^{\mathrm{a}}$ & $5.67 \pm 0.58^{\mathrm{a}}$ & $5.33 \pm 0.58^{\mathrm{a}}$ \\
\hline Moisture & $66.10 \pm 11.60^{\mathrm{a}}$ & $10.00 \pm 0.00^{\mathrm{b}}$ & $10.00 \pm 1.00^{\mathrm{b}}$ & $10.67 \pm 0.58^{\mathrm{b}}$ & $7.67 \pm 0.58^{\mathrm{b}}$ \\
\hline Nitrogen free extract & $6.75 \pm 5.59^{\mathrm{b}}$ & $34.33 \pm 1.53^{\mathrm{a}}$ & $34.67 \pm 1.15^{\mathrm{a}}$ & $33.67 \pm 0.58^{\mathrm{a}}$ & $37.67 \pm 2.08^{\mathrm{a}}$ \\
\hline Kcal & $1166.84 \pm 455.29^{\mathrm{b}}$ & $2747.00 \pm 27.71^{\mathrm{a}}$ & $2843.00 \pm 29.87^{\mathrm{a}}$ & $2881.33 \pm 26.03^{\mathrm{a}}$ & $2807.10 \pm 40.27^{\mathrm{a}}$ \\
\hline Potassium & $30.50 \pm 0.14^{\mathrm{a}}$ & $30.38 \pm 0.13^{\mathrm{a}}$ & $29.38 \pm 0.38^{\mathrm{b}}$ & $30.63 \pm 0.13^{\mathrm{a}}$ & $16.25 \pm 0.00^{\mathrm{c}}$ \\
\hline Magnesium & $11.59 \pm 0.56^{\mathrm{a}}$ & $11.58 \pm 0.48^{\mathrm{a}}$ & $11.61 \pm 0.49^{\mathrm{a}}$ & $11.51 \pm 0.54^{\mathrm{a}}$ & $11.03 \pm 0.55^{\mathrm{b}}$ \\
\hline Calcium & $61.96 \pm 1.77^{\mathrm{a}}$ & $64.47 \pm 3.20^{\mathrm{a}}$ & $61.52 \pm 3.13^{\mathrm{a}}$ & $53.10 \pm 2.49^{b}$ & $51.25 \pm 1.81^{\mathrm{b}}$ \\
\hline Sodium & $6.88 \pm 0.36^{\mathrm{d}}$ & $7.04 \pm 0.03^{\mathrm{cd}}$ & $7.29 \pm 0.02^{\mathrm{b}}$ & $7.73 \pm 0.04^{\mathrm{a}}$ & $5.25 \pm 0.07^{\mathrm{e}}$ \\
\hline
\end{tabular}

Note: Means with the same superscript within the same row are not significantly different $(\mathrm{P}>0.05)$

$\mathrm{SU}-$ raw

$\mathrm{SD}_{1}-$ Sundried for 24 hours

$\mathrm{SD}_{2}$-Sundried for 48 hours

$\mathrm{SD}_{3}$-Sundried for 72 hours

$\mathrm{SB}_{5}$ - Soaking in boiled water $\left(100^{\circ} \mathrm{C}\right)$ for 5 minutes

The sample soaked in boiled water at $100^{\circ} \mathrm{C}$ for 5 minutes $\left(\mathrm{SB}_{5}\right)$ had the highest crude fibre value of $14.33 \%$ while the sundried treatments were between 9.33-12.67\%. $\mathrm{SB}_{5}$ had the highest nitrogen free extract (37.67\%) and $\mathrm{SD}_{3}$ (sundried for 72 hours) had the least $(33.61 \%)$. However, the nitrogen free extract was not significantly different $(\mathrm{P}>0.05)$ for sundried and soaked in boiled water samples.

The mineral composition of differently processed Leucaena leaves as presented in Table 1 shows that processing led to a reduction in the minerals. The sundried treatments had higher values for all the minerals evaluated when compared with the soaked in boiled water treatment.

The anti-nutrients composition of differently processed Leucaena leaves as presented in Table 2 shows that there was a reduction in anti-nutrients of processed leaves when compared with the raw sample (SU). Furthermore the anti-nutrients were higher in the sundried treatments $\left(\mathrm{SD}_{1}, \mathrm{SD}_{2}\right.$ and $\left.\mathrm{SD}_{3}\right)$ than the 
treatment soaked in boiled water $100^{\circ} \mathrm{C}$ for 5 minutes $\left(\mathrm{SB}_{5}\right)$. The anti-nutrients values in the sundried treatments were significantly different $(\mathrm{P} \leq 0.05)$ from the treatment soaked in boiled water $100^{\circ} \mathrm{C}$ for 5 minutes $\left(\mathrm{SB}_{5}\right)$ with the exception of cyanide. The phytate content was highest $(0.71 \mathrm{mg} / 100 \mathrm{~g})$ in $\mathrm{SD}_{3}$ followed by $\mathrm{SD}_{2} 0.66 \mathrm{mg} / 100 \mathrm{~g}$, then $\mathrm{SD}_{1}$ with $0.61 \mathrm{mg} / 100 \mathrm{~g}$, while $\mathrm{SB}_{5}$ was least with $0.25 \mathrm{mg} / 100 \mathrm{~g}$ .Treatment $\mathrm{SB}_{5}$ gave $73 \%$ reduction of phytate, while $\mathrm{SD}_{1}, \mathrm{SD}_{2}$ and $\mathrm{SD}_{3}$ gave $23-33 \%$ reduction respectively. The tannin content was highest in $\mathrm{SD}_{3}$ with a value of $0.62 \mathrm{mg} / 100 \mathrm{~g} \mathrm{SD}_{1}$ had $0.61 \mathrm{mg} / 100 \mathrm{~g}$ and $\mathrm{SD}_{2}$ with $0.51 \mathrm{mg} / 100 \mathrm{~g}$, while $\mathrm{SB}_{5}$ had the least $0.2 \mathrm{mg} / 100 \mathrm{~g}$. The sundried treatments gave a tannin reduction of $41-50 \%$ while $\mathrm{SB}_{5}$ gave $81 \%$. The highest value of $0.64 \mathrm{mg} / 100 \mathrm{~g}$ for saponin was recorded in $\mathrm{SD}_{1}$ while $\mathrm{SB}_{5}$ had the least $(0.05 \mathrm{mg} / 100 \mathrm{~g})$. The percentage reduction of saponin for the treatment soaked in boiled water, $\mathrm{SB}_{5}$ was $97 \%$, while that of the sundried was 55$57 \%$ as shown in Table 2 . The mimosine content of the sundried treatments was highest $(1.28 \%)$ in $\mathrm{SD}_{3}$ and least $(1.07 \%)$ in $\mathrm{SB}_{5}$. The percentage reduction of mimosine was $23-27 \%$ for $\mathrm{SD}_{1}, \mathrm{SD}_{2}$ and $\mathrm{SD}_{3}$ while the treatment soaked in boiled water $100^{\circ} \mathrm{C}$ for 5 minutes $\mathrm{SB}_{5}$ had (36\%) reduction of mimosine.

The result shows that processing methods (sun-drying and soaking in boiled water) affected the proximate composition of Leucaena leaves. The high crude protein in the sundried treatments may be as a result of concentration of soluble solids thereby increasing the drymatter. Mbah et al. (2012) reported a similar increase in protein when Moringa oleifera leaves were sundried. The reduction of crude protein in the soaked treatment $\left(\mathrm{SB}_{5}\right)$ may be due to leaching of soluble nutrients (Nuttaporn and Naiyatat, 2009). The low crude protein value observed in the $\mathrm{SB}_{5}$ treatment could also be associated with loss of amino acids especially sulphur amino acids, methionine + cysteine. Madalla et al. (2013) reported a reduction in values of methionine and cystiene by $67 \%$ when Moringa leaves were soaked in water overnight. The variation in the crude protein values of the different processing methods in this study and that of previous studies could be attributed to differences in duration of sun-drying, hours of soaking, temperature of water and method of soaking (Masafu, 2006). The high value of crude fibre in $\mathrm{SB}_{5}$ treatment may be due to loss of nutrients that are soluble in water, leaving insoluble fibre. The nitrogen free extract values were higher in the Leucaena leaves soaked in boiled water when compared with the sundried Leucaena leaves. This observation may be due to the lower levels of other proximate components (crude protein, crude fibre, ash and ether extract) since nitrogen free extract values are obtained by subtracting other components. Previous studies also reported high nitrogen free extract values for soaked and cooked Leucaena leaves when compared with sundried Leucaena leaves (Osman et al., 1996; Adekojo et al., 2014).

Table 2: Effects of processing on the Anti-nutrients Composition of Leucaena leucocephala Leaves

\begin{tabular}{llllll}
\hline Anti-nutrients & & \multicolumn{3}{c}{ Treatments } \\
\hline$(\mathrm{mg} / 100 \mathrm{~g})$ & $\mathrm{SU}$ & $\mathrm{SD}_{1}$ & $\mathrm{SD}_{2}$ & $\mathrm{SD}_{3}$ & $\mathrm{SB}_{5}$ \\
\hline Phytate & $0.91 \pm 0.2^{\mathrm{a}}$ & $0.61 \pm 0.05^{\mathrm{b}}$ & $0.66 \pm 0.02^{\mathrm{b}}$ & $0.71 \pm 0.09^{\mathrm{b}}$ & $0.25 \pm 0.03^{\mathrm{c}}$ \\
\% Reduction & - & 33 & 28 & 22 & 73 \\
Cyanide & $0.50 \pm 0.1^{\mathrm{a}}$ & $0.07 \pm 0.01^{\mathrm{b}}$ & $0.05 \pm 0.01^{\mathrm{b}}$ & $0.07 \pm 0.01^{\mathrm{b}}$ & $0.05 \pm 0.01^{\mathrm{b}}$ \\
$\%$ Reduction & - & 86 & 90 & 86 & 90 \\
Tannin & $1.03 \pm 0.33^{\mathrm{a}}$ & $0.61 \pm 0.01^{\mathrm{b}}$ & $0.51 \pm 0.23^{\mathrm{b}}$ & $0.62 \pm 0.01^{\mathrm{b}}$ & $0.2 \pm 0.02^{\mathrm{c}}$ \\
$\%$ Reduction & - & 41 & 50 & 40 & 81 \\
Saponin & $1.43 \pm 0.48^{\mathrm{a}}$ & $0.64 \pm 0.01^{\mathrm{b}}$ & $0.46 \pm 0.04^{\mathrm{b}}$ & $0.62 \pm 0.04^{\mathrm{b}}$ & $0.05 \pm 0.01^{\mathrm{c}}$ \\
$\%$ Reduction & - & 55 & 68 & 57 & 97 \\
Mimosine (\%) & $1.66 \pm 0.02^{\mathrm{a}}$ & $1.25 \pm 0.01^{\mathrm{b}}$ & $1.22 \pm 0.01^{\mathrm{b}}$ & $1.28 \pm 0.03^{\mathrm{b}}$ & $1.07 \pm 0.04^{\mathrm{c}}$ \\
\% Reduction & - & 25 & 27 & 23 & 36
\end{tabular}

Note: Means with the same superscript within the same row are not significantly different $(\mathrm{P}>0.05)$

$\mathrm{SU}-\mathrm{raw}$

$\mathrm{SD}_{1}-$ Sundried for 24 hours

$\mathrm{SD}_{2}-$ Sundried for 48 hours

$\mathrm{SD}_{3}$ - Sundried for 72 hour

$\mathrm{SB}_{5}$ - Soaking in boiled water $\left(100^{\circ} \mathrm{C}\right)$ for 5 minutes

The positive effects of the processing methods in the line with the reports of Fayemi et al. (2011) and reduction of most anti-nutritional compounds are in Adekojo et al. (2014). Similar reductions of various 
anti-nutritional compounds were reported when Leucaena leaves were subjected to sun-drying, soaking and fermentation (Fayemi et al., 2011; Adekojo et al., 2014). Soaking in boiled water $\left(100^{\circ} \mathrm{C}\right)$ for 5 minutes was able to reduce the levels of various anti-nutritional compounds better than sun-drying. The lower value of mimosine and other anti-nutritional compounds recorded for soaking in boiled water $\left(100^{\circ} \mathrm{C}\right)$ for 5 minutes processing method has been reported by previous authors when Leucaena leaves were soaked in hot or cold water (Osman et al., 1996: Baraigi et al., 2004; Fayemi et al., 2011). The high value of minerals such as phosphorus, potassium, magnesium and calcium in the sundried treatments when compared with $\mathrm{SB}_{5}$ treatment could be as a result of reduction of moisture while the low minerals value observed in $\mathrm{SB}_{5}$ treatment could be due to leaching. Adekojo et al. (2014) gave a similar report when Leucaena leaves were soaked in $60^{\circ} \mathrm{C}$ water for 24 hours.

Conclusion: Soaking in boiled water $\left(100^{\circ} \mathrm{C}\right)$ for 5 minutes increased palatability and digestibility of the Leucaena leaf meal due to the low levels of antinutrients therefore is recommended for inclusion in fish diet. The crude protein in the processed Leucaena leaves indicates it could serve as a supplement to other conventional proteins in fish feed.

\section{REFERENCES}

Adekojo, SA; Adama, TZ; Aremu, A; Ijaiya, AT (2014). Effects of different methods of processing Leucaena leucocephala leaf-meal on growth performance and nutrient digestibility of rabbits. International Journal of Agriculture and Forestry. 4(5): 380-385.

A.O.A.C. (1990). Official Methods of Analysis Association of Official Analytical Chemistry vol.13 Washington, USA pp. 1234.

Aye, PA (2012). Effect of processing on the nutritive characteristics, anti-nutritional factors and functional properties of Cnidoscolus aconitifolius leaves (IyanaIpaja). American Journal of Food and Nutrition. Online: ISSN 2157-1317, doi:10.5251/ajfn.2012.2.4.89.95 (C) 2012, Accessed: 09/03/2016

Ayssiwede, SB; Zanmenou, JC; Issa, Y; Hane, MB; Dieng, A; Chrysostome, AM; Houinato, MR; Hornick, JL; Missohou, L (2011). Nutrient composition of some unconventional and local feed resources available in Senegal and recoverable in indigenous chicken or animal feeding. Pakistan Journal of Nutrition,10(8): 707711.

Baraigi, A; Ghosh, SK; Ray, AK (2004). Evaluation of nutritive value of Leucaena leucocephala leafmeal inoculated with intestinal bacteria (Bacillus subtilis and Bacillus circulan) in formulated diet for Rohu (Labeo rohita) Ham fingerlings. Aquaculture Research, 35 (5): 436-446.

FACT Sheet. (1997). Leucaena leucocephala: A Versatile nitrogen fixing tree, a quick guide to multipurpose trees from around the World. FACT, 97-06 September, 1997.

Fayemi, PO; Onwuka, CF; Isah, OA; Jegede, AV; Arigbede, OM; Muchenje, V (2011). Effects of mimosine and tannin toxicity on rabbits fed processed Leucaena leucocephala(Lam) De wit Leaves. African Journal of Agriculture Research, 6(17): 4081-4085.

Hertrampf, WJ; Piedda-Pascual, F (2003). Handbook on Ingredients for Aquaculture Feed. Kluwer Academic Publishers, pp.624.

Madalla, N; Agbo, W; Jauncey, K (2013). Evaluation of aqueous extracted moringa Leaf-meal as a protein source for nile tilapia juveniles. Tanzania Journal of Agricultural Sciences, 12(1): 53-64

Masafu, MM (2006). The evaluation of Leucaena leucocephala (Lam) wit: A renewable protein supplement for low quality forages. (Unpublished Doctoral thesis). University of South African, Pretoria.

Mbah, BO; Eme, PF; Paul, AE (2012). Effect of Drying Techniques on the Proximate and Other Nutrient Composition of Moringa oleifera Leaves from Two Areas in Eastern Nigeria. Pakistan Journal of Nutrition. 11 (11):1044 - 1048.

Megarity, RG. (1978). An automated calorimetric method for mimosine in Leucaena leaves. Journal of the Science of Food and Agriculture, 29(2): 182-186.

Monoj, KG; Bandyopadhyay, SK (2007). Mimosine toxicity: A problem of Leucaena feeding in ruminants. Asian Journal of Animal and Veterinary advances, 2(2):63-73.

Nuttaporn, F; Naiyatat, P (2009). The reduction of mimosine and tannin content in leaves of 
Leucaena leucocephala. Asian Journal of Food and Agro-Industry Special issue, S137-S144.

Osman, MF; Omar, EA; Nour, AM (1996). The use of Leucaena in feeding Nile tilapia. Aquaculture International, 4: 9-18.
Pauzenga, U (1985). Feeding parent stock. Zootecnica International, 22-24pp.

Wheeler, EI: Ferrel, RE (1971). Methods for phytic acid determination in wheat and wheat Fractions. Cereal Chemistry, 84:312-320 